\title{
Applying anthropology to what? Tactical/ethical decisions in an age of global neoliberal imperialism
}

\author{
James R. Veteto ${ }^{1}$ \\ Joshua Lockyer \\ Western Carolina University, USA \\ Arkansas Tech University, USA
}

\begin{abstract}
This article introduces the Journal of Political Ecology Special Section on 'towards a political ecology of applied anthropology.' We provide a brief overview and analysis of the history and application of applied and practicing anthropology. Examining moral and ethical issues related to the application of anthropology, we assess current endeavors and make suggestions for future directions from a political ecology perspective. Introducing five articles that exemplify our approach, we identify common themes and particular contexts that both unify and distinguish each of the contributions. Throughout this introduction, we propose a potential guidepost for a political-ecology informed applied anthropology: any applied anthropology that engages, documents, promotes, and supports cultural diversity, social justice and environmental sustainability is just. Conversely, any applied anthropology that threatens cultural diversity and environmental sustainability is unjust.
\end{abstract}

Key words: applied anthropology, imperialism, political ecology, neoliberalism, ethics

\section{Résumé}

Cet article présente une section spéciale du Journal of Political Ecology, "Vers une écologie politique de l'anthropologie appliquée». Nous fournissons un bref aperçu et une analyse de l'histoire et de l'application de l'anthropologie appliquée. Nous évaluons les efforts actuels et faire des suggestions pour les orientations futures dans une perspective de l'écologie politique. Nous examinons également les questions morales et éthiques liées à l'application de l'anthropologie. Nous identifions des thèmes communs et des contextes particuliers qui unissent et distinguent chacune des cinq articles dans cette section spéciale. Tout au long de cette introduction, nous vous proposons un panneau potentiel pour une anthropologie appliquée informé par la politique et l'écologie. Toute l'anthropologie appliquée qui engage, qui document, qui promeut et soutient la diversité culturelle, la justice sociale et la durabilité environnementale est juste. Inversement, toute l'anthropologie appliquée qui menace la diversité culturelle et la durabilité environnementale est tout simplement pas.

Mots clés: anthropologie appliquée, l'impérialisme, l'écologie politique, le néolibéralisme, le éthique

\section{Resumen}

Este artículo sirve de Introducción a la sección especial de la Journal of Political Ecology sobre la ecología política de la antropología aplicada. Ofrecemos un breve recorrido de la historia y aplicación de la antropología aplicada y practicada. Examinamos asuntos morales y éticos relacionados a la aplicación de la

\footnotetext{
${ }^{1}$ Dr. James R. Veteto, Assistant Professor of Anthropology, Anthropology and Sociology Department, Western Carolina University, Cullowhee, NC 28723, USA. Email: jrveteto "at" wcu.edu. Dr. Joshua Lockyer, Assistant Professor of Anthropology, Department of Behavioral Sciences, Arkansas Tech University, Russellville, AR 72801, USA. Email: jlockyer "at" atu.edu. The authors thank JPE editor Casey Walsh and the reviewers for their helpful insights. We also thank the participants in the double panel Destination: Ecotopia at the 2014 Society for Applied Anthropology meeting in Albuquerque, NM, USA where the gestation for this Special Section began. This work would not have been possible without the inspiration provided by all the activists with whom we have worked in pursuit of a more just and sustainable world nor without the scholar-activists that have preceded us. This is the introductory paper in James Veteto and Joshua Lockyer (eds.) 2015. "Towards a political ecology of applied anthropology", Special Section of the Journal of Political Ecology 22: 357-465.
} 
antropología, evaluamos esfuerzos actuales para llevar a cabo este enfoque, y sugerimos algunas orientaciones hacia el futuro, desde el enfoque de la ecología política. Introducimos seis artículos ejemplares de este enfoque, identificando temas comunes y contextos específicos que sirven para unir a las contribuciones y distinguir a cada una. Utilizamos un definición de la antropología aplicada informada por la ecología política, que puede servir como hito: cualquier antropología aplicada es justa cuando dialogo con, documenta a, promueve y apoya a la diversidad cultural, la justicia social y la sustentabilidad ambiental. De manera inversa, cualquier antropología que amenaza a la diversidad cultural y sustentabilidad ambiental es injusta.

Keywords: antropología aplicada, imperialismo, ecología política, neoliberalismo, ética.

\section{Ethical dilemmas in applied anthropology}

In this Special Section, we are interested in starting (or continuing, for those who have already been engaging it) a discussion regarding the nature and aims of applied anthropology by viewing this field through the lens of political ecology. In doing so, we identify some ethical signposts for applied anthropology and we highlight selected recent work in applied political ecology that simultaneously promotes social justice and environmental sustainability. Applied anthropology has been an important component of the anthropological enterprise since its inception, waxing and waning in perceived significance throughout the history of the discipline. From the 1970s forward, as the overproduction of PhDs in anthropology made the job market in academia increasingly bleak, a growing number of anthropologists have found themselves in applied/practicing positions outside of the academy. In this context, we would like to assess what kind of anthropological work might be useful in the current era of the Anthropocene (Zalasiewicz et al. 2011), a sort of time-honored 'taking stock' of what kind of moral and ethical assumptions should guide our research and to what sort of endeavors we should apply our work.

Humanity finds itself in a precarious position. Our species currently numbers over seven billion members, more than double the three billion that resided on the planet in 1960 and an exponential increase over the one billion humans extant at the onset of the Industrial Revolution. The top 1\% of the wealthiest elite on the planet control 50\% of economic resources (Fuentes-Nieva and Galasso 2014) and wealth concentration and disparity is increasing within nations and globally. Economic elites are responsible for greater resource consumption and more of the resulting social inequity and environmental destruction than the masses of the world's peoples combined. Disparities show themselves along the lines of race, ethnicity, class, gender, and other important socio-cultural variables. Uneven wealth distribution and access to resources manifests within countries and between them, with unevenness particularly glaring between the Global North and South. Thus, in 2011, the average American consumed as much annually as 144 Bangledeshis (Brown 2011). Yet, even within the richest country in the world, the US, there are striking disparities between rich and poor, and consequently, between the ecological and social footprints of elites and non-elites. Since the global economic recession of 2008, 97\% of the modest benefits of the US economic recovery have gone to elites, virtually shutting out the shrinking middle class and the burgeoning lower classes from any social or economic gains (Fuentes-Nieva and Galasso 2014).

It is within this context of growing global oligarchy and plutocracy and attendant socio-environmental crises that humanity and anthropology find ourselves enmeshed. The social and ecological consequences of global neoliberalism ${ }^{2}$ are dire, manifested in almost every aspect of the world's diverse biocultural landscapes. Anthropogenic climate change is causing unprecedented disruptions in planetary climate

\footnotetext{
${ }^{2}$ We recognize the lack of consensus and clarity regarding the meaning of the term neoliberalism. We are working from an understanding of neoliberalism that accords with definitions by Paul Treanor and David Harvey. Treanor (2005) characterizes neoliberalism as: "...a philosophy in which the existence and operation of a market are valued in themselves, separately from any previous relationship with the production of goods and services, and without any attempt to justify them in terms of their effect on the production of goods and services; and where the operation of a market or market-like structure is seen as an ethic in itself, capable of acting as a guide for all human action, and substituting for all previously existing ethical beliefs." Harvey’s (2005:2) definition of neoliberalism, in part, is as follows: "Neoliberalism is in the first instance a theory of political economic practices that proposes that human well-being can best be advanced by liberating individual entrepreneurial freedoms and skills within an institutional framework characterized by strong private property rights, free markets and free trade. The role of the state is to create and preserve an institutional framework appropriate to such practices."
} 
patterns, resulting in extreme weather events with tragic consequences for human communities (IPCC 2013; Wolverton et al. 2014). Biocultural diversity losses are staggering; some estimates indicate 150 species of biological organisms are being lost per day, a rate of extinction that is surpassed by the annual percentage of disappearing human languages (Maffi 2001; Sutherland 2003). The world's oceans and fisheries are being poisoned and depleted at increasingly alarming rates. Environmental pollutants are causing damage to watersheds, with local communities and marginalized peoples suffering the worst consequences (Checker 2007; Saxton 2015). Unsustainable industrial agriculture is depleting global soils, eroding thousands of years of accumulated agrobiodiversity, and polluting waterways (Cleveland 2014). The legacy of pollution from nuclear waste and war is enduring and ongoing (Johnston 2007). The number of armed conflicts across the world is increasing at least in part due to growing political and economic inequalities. Waves of political and environmental refugees are growing at rates impossible for social structures to keep up with (Brown 2011). The list goes on and on.

If the dire nature of the current situation is the outcome of numerous socio-environmental crises, how should anthropology respond? How, with whom, and toward what ends should we be applying anthropological methods and knowledge? What kind of work should we be doing and promoting? Applied anthropology has been variously promoted as a panacea to the limitations of approaches (both academic and popular) in various human endeavors (e.g. Henry et al. 2013; Rhoades 2005; Wasson 2000) or (famously and enduringly) deconstructed as the "handmaiden of colonialism" (e.g. Asad 1973; Escobar 1995, 1991). We think applied anthropology can embody, depending on how it is utilized, either of these two polarized characterizations, variously falling on a continuum from one essentialism to the other. Within this context, however, we are not promoters of applied anthropology writ large.

Although both the discipline of anthropology and the whole of humanity that falls within its range of study are both mesmerizingly complex, we see the issue we are discussing as fairly clear-cut and can summarize it succinctly. Regarding the application of anthropology, we ask, is research aimed at documenting, celebrating, promoting, and protecting (where needed) human cultural diversity? Furthermore, following prominent social science thinkers in what has somewhat recently been coined the 'ontological turn' (Descola 2013; Latour 2014) and perhaps more importantly, various indigenous perspectives (Atleo 2012, 2004; Deloria 1979: Martinez 2003; Salmon 2012, 2003), we do not recognize an ontological divide between nature and culture. It follows, therefore, that any anthropology that is generally supportive of cultural diversity will also be dedicated to the study, promotion, and protection (where needed) of ecological diversity. Our position, then, can be summarized as: Any applied anthropology that that engages, documents, promotes, and supports cultural diversity, social justice and environmental sustainability is just. Conversely, any applied anthropology that threatens cultural diversity and environmental sustainability is unjust.

\section{Applied anthropology and the practicality of employment}

In the current neoliberal context, the practicality of gaining employment in jobs that study, promote, or protect cultural and ecological diversity and expression are minimal, although some opportunities do exist. Alternatively, if one wants to gain employment as an anthropologist in consumer research, military operations, helping improve corporate efficiency, or other capitalist/imperialist enterprises, there is a better chance of finding a well-paying career (although it is still challenging). In the current global economy where only money talks, funding for practice outside the military-industrial-market complex is increasingly scarce. This presents an ethical dilemma for anthropology as whole and especially for those anthropologists working in applied or practicing domains.

Is it ethical to shepherd graduate students toward PhDs in academic anthropology when they might spend years chronically underemployed in university teaching as adjuncts for less than minimum wage salaries and no employment benefits, after accruing between three and ten years of student debt (Deresiewicz 2011; Miller 2011)? Or are we ethically bound to produce students who will be legitimate wage-earners in the current neoliberal capitalist economy? This is a debate currently taking place in many of the anthropological circles we travel in. Some applied anthropologists think they have found a way out: training 
students in applied MA/MS or PhD programs that will better prepare them to get applied and practicing jobs outside academia, where the job market is somewhat less saturated.

The logic of this argument is generally sound and we do not fully disagree with it. In fact, we are in favor of this approach when it produces students, for example, who are working to help an Indigenous NGO in Brazil navigate the complexities of conservation and sustainable development; or are working with an African-American community garden and health organization. However, we are not supportive of training students to help a corporation design the newest technological gadgetry or to find ways to market their wares to a more diverse audience so CEOs can get bigger bonuses. We have spent the bulk of our lives working for social justice and environmental sustainability. Therefore, we do not support the training of students in the discipline we love, to help destroy the very ground that anthropology stands on (and presumably, for). We return to our edict above: Any applied anthropology that that engages, documents, promotes, and supports cultural diversity, social justice and environmental sustainability is just. Conversely, any applied anthropology that threatens cultural diversity and environmental sustainability is unjust.

The issue is obviously not as simple as we have outlined above. Focusing on certain segments of applied anthropology in the context of a shrinking job market that is, for the most part, only producing employment in the neo-liberal capitalist growth-recession-depression engine could be seen as blaming the victim. After all, anthropologists are not responsible for creating the current world system, are we? A significant amount of applied anthropological work has had a positive impact in terms of justice and sustainability (e.g. Hunn 1999; Rhoades 2007; Scheper-Hughes 1995), but we have also been utilized as colonial administrators in Africa (Asad 1973), government bureaucrats and academic researchers involved in questionable dealings and policies with American Indians (Deloria 1969), as aids to American military interventions through the Human Terrain Systems program (González 2012), as proponents of designing and marketing corporate products (Wasson 2000), helping manage internment camps for Japanese-Americans in World War II (Starn 1986); and as President and other high level administrators of arguably the most imperialistic development agency on the planet, the World Bank (Bond 2012).

The history and current state of applied anthropology is a mixed bag and arguably always will be. We have sympathy for students and practitioners who join industry or development agencies with the aim of augmenting their cultural sensitivity, diverse hiring practices, or other important social variables. This is a reformist position that we, recognizing and respecting the fact that not everyone in the discipline shares our worldview, ultimately do not agree with (e.g. James 1973). Some reformist jobs are arguably in line with the central edict we issued above. We can imagine, for instance, business anthropologists coming from a radical perspective who take jobs organizing workers or helping develop green energy technologies? We are in favor of such work where it occurs. What we really think this boils down to is the ontological, epistemological, moral, and ethical grounding that is taken to be the foundation of anthropological practice. Are you working from a radical perspective that rejects dualistic ontologies and supports social justice and environmental sustainability and are just stuck in a bad job until something better comes along, or have you found employment that aligns well with your values? What personal and career choices have led you to the position you are currently in, and do you have the option of heading in a different direction? These are not uncommon dilemmas for those who envision anthropology as a radical quest for a socially-just, environmentally healthy world. Indeed, we think most applied anthropologists can relate to such ethical dilemmas and tactical decisions in our current age of neoliberal imperialism.

However, we also find that many (most?) applied anthropologists do not come from an ontological and moral grounding such as we have described above. The dominant global hegemony that we are all enculturated or acculturated into, albeit in different contexts, is neoliberal capitalism. Inherent within the dominant world-system is an ontological dualism that separates humans from nature, mind from body, and subject from object (Biersack 2006; Descola 2013; Ingold 2011; Latour 1993). We are taught from a young age to maximize our own individual happiness and utility and to accumulate capital at all costs, regardless of the impact on the other beings and the landscapes we are part of. As anthropologists, we have long questioned assumptions about, for instance, the ubiquity of Western cultural norms; however, as a discipline, we have a harder time doing the intellectual and personal work it takes to challenge the neoliberal cultural training that professors and students have received-and indeed, the whole edifice of Western civilization in 
late vulgar capitalism — as an explicit part of our professional training and career trajectories. Yet, this is the work to be done (e.g. Donham 1999; Marcus and Fischer 1999), in our minds, if any of us are to have a future on this planet (see, on the climate change crisis, IPCC 2013). If we train future anthropologists with the normative assumptions of neoliberal capitalism and Western cultural values, albeit with a multicultural bent, we can expect no change in the direction global society is headed (see Escobar 1991 for similar insights on development anthropology). If we champion anthropologists who have made careers for themselves in fields that promote the capitalist project, in practical and ethical terms, we do not see how anthropology has any higher moral ground than other disciplines such as business studies or classical economics.

Take, for example, an article from the New York Times (Singer 2014) that promotes the work of practicing cultural anthropologist Genevieve Bell as the Intel Corporation's "resident tech intellectual." At Intel, Bell runs a research lab that is deeply involved in helping the company's product development process and is:

...responsible for sussing out the attributes that people everywhere love, or wish they could have, in their PCs, televisions and so on. Over the last few years, they have been concentrating on consumers' appetites for hyper-personal technology, like voice-recognition systems and fitness trackers. In essence, they are pushing Intel toward a more people-centric era of personal computing (Singer 2014).

The article lauds Bell for the innovative type of cultural anthropology-informed consumer research she does in a rapidly globalizing and digitalizing world. The underlying assumption is, we infer, that anthropologists can help everyone achieve a modern Western lifestyle, while Intel makes billions of dollars. This might be a viable proposition if we had access to seven more empty, habitable planets since we are arguably already living beyond the carrying capacity of our present one (Brown 2011; Wackernagel et al. 2002). Since the American Anthropological Association (AAA) featured the Times article on Bell on the front of their webpage soon after it was published, maybe she is the type of applied anthropologist we should all aspire to be. What we really think the AAA is trying to say is; "Look everybody! Here is an anthropologist who is doing relevant work in the real world, most likely has her student loans paid off, and is achieving social mobility!"

What the Times articles does not discuss, unsurprisingly, is how Bell will design solutions for providing living wages and health care to all of the exploited adult and child labor in the Global South that is involved in mining the precious minerals used for making the Intel processors that she is so slickly helping to market. Nor does it address the health outcomes of the polluted conditions experienced by factory workers that are producing the technological gadgets in which those processors are embedded (Little 2013). How is Bell going to address the disposal of the Intel electronic devices that will be discarded a few years after purchase-because of planned obsolescence-containing, as they do, numerous hazardous chemicals? What will Bell say to the local (usually some combination of people of color, Indigenous, rural, poor, and/or Global South) communities who are the recipients of the mountains of electronic trash that are building each year? How is Dr. Bell, whose mandate at Intel, "has always been to bring the stories of everyone outside the building inside the building" (Singer 2014), going to design mechanisms to offset the massive carbon emissions that Intel corporation is responsible for in every aspect of their business-from the mining of precious minerals to factory produced digital consumables shipped around the world to various manufacturers and sales outlets? We are suspicious that stories from marginalized people and endangered species who are suffering the brunt of worker exploitation and climate change are, in fact, 'left outside the building' by Dr. Bell and other anthropologists employed in comparable positions. Any anthropologist knows that we can choose whose stories to privilege and whose to leave out. The Times article does not delve into any of these questions or finer details. Is Dr. Bell's work a guidepost for applying anthropology in the modern world or a harbinger of doom? 


\section{Toward a political ecology-informed applied anthropology}

The questions we have raised above are likely to be unwelcome to some, given the disciplinary fissures that anthropology experienced during the 1980s and 90s with the postmodern challenge and 'science wars' - a context we are not trying to revisit in any form. Since most individuals with a higher degree in anthropology today are, and will undoubtedly continue to be, working outside of higher education, we need to continue to take stock of how anthropology is applied, with whom, and toward what ends. The ontological, epistemological, theoretical, moral, and ethical questions (all of which are political) facing us have not gone away and are complex and multi-faceted, which is true of any domain that anthropology engages in. We have proposed one guidepost for assessing applied anthropological work: Any applied anthropology that that engages, documents, promotes, and supports cultural diversity, social justice and environmental sustainability is just. Conversely, any applied anthropology that threatens cultural diversity and environmental sustainability is unjust. There is not going to be any perfect judgment in applying such a barometer. Inevitably, and we have experienced this as both academics and activists, some individuals who are explicitly pursuing just and applied work will turn out to be doing the opposite and some individuals who are not trying to produce just work will do so. We attribute this phenomenon to the messy nature of human intentions and outcomes, which anthropologists are part of. The point here is that we need to pay more deliberate attention to- that we need to put front and center-our intentions and the actual outcomes of them within the larger structural context of global neoliberalism and its attendant socio-environmental crises.

The work highlighted in this Special Section is continuing a tradition of research that we think aligns very well with the type of political ecology-informed approach to applied anthropology we are advocating. For example, Barbara Rose Johnston's long-term research and human rights activism as a political ecologist has been influential in various domains, including prominently the analysis of legacies of pollution and discrimination stemming from nuclear weapons and energy production (Johnston 2007, 2011). Well-known ethnobotanist Gary Paul Nabhan has done extensive applied and public work promoting agrobiodiversity conservation, indigenous rights, food sovereignty, landscape conservation and restoration, climate change, and general environmental awareness (Nabhan 1989, 1997, 2002, 2008, 2013). Arturo Escobar has been a consistent critic of Western development ideologies and strategies, deconstructing ontological categories such as nature and culture, and advocating for alternative possibilities rooted in subaltern strategies of localization stemming from his long-term fieldwork among Afro-Columbian groups on the Columbian Pacific coast (Escobar 2008, 2001, 1995, 1991). Work exemplifying our approach has also been done on diverse topics such as non-capitalist political ecologies (Burke and Shear 2014), hydrological fracking (Simonelli 2014; Willow and Wylie 2014), agricultural anthropology (Campbell and Veteto 2015; Rhoades and Booth 1982; Veteto and Crane 2014, Veteto 2014), climate change (Crate and Nuttall 2009; Lockyer 2010a; Veteto and Carlson 2014), food justice (Cadieux and Slocum 2015), historical ecology (Armstrong and Veteto 2015; Egan 2005), campus sustainability (Barlett and Chase 2013; McKenna 2012), Native anticlearcutting activism (Willow 2012); and bioregionalism, permaculture, and ecovillages (Lockyer 2010b; Lockyer and Veteto 2012; Lockyer and Veteto 2013; Veteto and Lockyer 2008), among many others.

\section{Tactical decisions: contributions to the Special Section}

In this Special Section, we bring together a collection of current work in applied anthropology that exemplifies the political ecology-informed approach we are advocating. Most of the contributors are employed in academia, ranging from tenured professors of anthropology and environmental studies to graduate students just setting out in the field. Our contributors work in settings that span the globe; collectively, they work on three different continents in Brazil, Mexico, Bulgaria, and the United States. Each of the contributors brings to their ethnographic research a sensitivity to the practical roles played by applied anthropologists and researchers in the political struggles of the people they work with, and in the broader pursuit of social justice and environmental sustainability.

The first article, by Dvera Saxton (2015), is set in the industrial agricultural fields of north-central California where, in the course of her ethnographic research with farmworkers, Saxton was faced with a request for assistance from the participants in her research. The farmworkers, many of them of Mexican 
origin, were seeking recourse for the negative health impacts of exposure to toxic soil fumigants in the course of their work, but were having difficulty navigating the complex webs of science, institutions, and activism they confronted. Adopting the role of researcher-activist, Saxton spent several years doing multi-sited research in collaboration with her farmworker interlocutors. In the process, and drawing on similar work in the field of environmental justice by other anthropologists, she developed what she calls a set of "ethnographic movement methods" through which the activities and goals of anthropological research and political ecology are synced with the activities and goals of social and environmental justice movements. With Saxton's help, the farmworkers have achieved some success in establishing more stringent regulations for the use of toxic soil fumigants.

The focus on marginalized populations struggling for social and environmental justice continues in the second and third articles in this collection. Lucero Radonic and Sarah Kelly-Richards (2015) conducted research in two separate, rapidly urbanizing areas of northern Mexico where local colonias and barrios (neighborhoods) have struggled for decades with lack of/inadequate water and sanitation infrastructure. In both contexts, the authors found themselves navigating between hegemonic discourses of government agencies that elide the reality of marginalized communities, and forms of insurgent citizenship through which residents address their daily needs through alternative, unofficial strategies. The authors suggest that applied anthropologists can help to find realistic solutions to the 'wicked problems' faced by these populations by using a political ecology-informed praxis to bring the complex realities of local neighborhoods into dialogue with neoliberal strategies of state agencies, in the process helping marginalized peoples find their voice in the pursuit of realistic, effective solutions.

The third article, by David Meek (2015), employs a political ecology of education framework in the context of an alternative school in the Brazilian Landless Workers Movement. Meek demonstrates how the school's curriculum draws on hybridized conceptions of educational space-time to foster critical thinking about the political economic processes that have led to the marginalization of the community, and to advance alternative land management strategies and forms of environmental knowledge that are constitutive of more just and sustainable forms of land tenure (based on the science of agroecology) than those promulgated by industrially-oriented paradigms of science and technology. Implicitly suggesting that this movement can help inform applied anthropologists toward transforming their own curricula to better empower students to envision and enact alternative futures, Meek provides an important example of how schools can critically educate students in understanding the political ecologies of their landscapes, in addition to helping them develop methodological and theoretical tools necessary to transform their realities to better reflect and empower social and environmental justice concerns.

Post-socialist Central and Eastern Europe is the context of the fourth article, where neoliberalism is ascendant, particularly in the form of modernization and industrialization of agriculture and the broader food system. June Brawner (2015) illustrates the ways in which rural populations in this region challenge and resist notions of progress inherent in the neoliberal narrative. The author highlights her work with a group of people who utilize the design science of permaculture to define alternative (to both capitalism and communism) political ecologies where approaches to agriculture and associated epistemologies are simultaneously diverse, decentralized, collaborative, just, and sustainable. She illustrates that permaculture presents models that stand in fundamental opposition to the foundations of dominant agro-food systems. In conclusion, Brawner suggests that applied environmental anthropologists might bolster their projects beyond the scope of social movements or as merely 'alternatives', by evaluating seriously the potential for permaculture as an oppositional framework.

The final contribution to this Special Section illustrates a political ecology-informed application of anthropology to the conservation and promotion of agricultural biodiversity and its role in achieving bioregional food sovereignty. Drawing on their work with farmers, gardeners, and seed savers in the southeastern United States, Brian Campbell and James Veteto demonstrate how traditional ethnographic research and collaborative conservation efforts go hand-in-hand and serve the explicit purpose of forging more sustainable and integrated local food systems. The authors argue that agricultural biodiversity conservation must be conducted in situ to be sustainable and that food insecurity needs to be addressed in ways that allow local communities greater control over the sources of their food. Drawing on their common 
experiences managing seed- and memory-banking projects that facilitate grassroots agricultural biodiversity conservation, Campbell and Veteto highlight specific ways in which particular seed varieties and research projects have connected them to diverse actors and methods involved in grassroots agrobiodiversity conservation.

Collectively, the articles in this Special Section illustrate how anthropologists not only can, but already are, applying the broad lens of political ecology as they conjoin research and activism in pursuit of greater social justice and environmental sustainability. They demonstrate that sound empirical research, the application of anthropological methods and insights to real-world problems, and the pursuit of ethical outcomes need not be mutually exclusive.

\section{Conclusion}

Anthropology will presumably continue to remain a highly heterogeneous and diverse discipline with respect to its intellectual assumptions and applied outcomes, which is, in general, a positive development. However, when anthropologists engage in work that damages the underlying biocultural matrix of humanity-e.g. that is contributing to the exploitation of workers, supporting social hierarchies, and helping destroy local ecosystems - we, as researchers and activists, cannot support or condone it. As argued throughout this introduction and exemplified by the diverse contributions below, we are advocating a political-ecology informed applied anthropology that is fully engaged in creating a socially-just and environmentally sustainable world for all.

\section{Towards a political ecology of applied anthropology, edited by James R. Veteto and Joshua Lockyer \\ 1. Dvera Saxton - Ethnographic movement methods: anthropology takes on the pesticide industry \\ 2. Lucero Radonic and Sarah Kelly-Richards - Pipes and praxis: a methodological contribution to the urban political ecology of water \\ 3. David Meek - Taking research with its roots: restructuring schools in the Brazilian landless workers' movement upon the principles of a political ecology of education \\ 4. June Brawner - Permaculture in the margins: realizing Central European regeneration \\ 5. Brian Campbell and James Veteto - Free seeds and food sovereignty: anthropology and grassroots agrobiodiversity conservation strategies in the US South}

\section{References}

Armstrong, C.G. and J.R. Veteto. 2015. Historical ecology and ethnobiology: applied research for environmental conservation and social justice. Ethnobiology Letters 6: 5-7.

Asad, T. 1973. Anthropology and the colonial encounter. New York: Ithaca Press.

Atleo, E.R. 2004. Tsawalk: a Nuu - Chah - Nulth worldview. BC, Canada: UBC Press.

Atleo, E.R. 2012. Principles of Twawalk: an Indigenous approach to global crisis. Seattle: University of Washington Press.

Barlett, P.F. and G.W. Chase (eds.). 2013. Sustainability in higher education: stories and strategies for transformation. Cambridge, MA: MIT Press.

Biersack, A. 2006. Reimaging political ecology: culture/power/history/nature. In A. Biersack and J.B. Greenberg (eds.) Reimaging political ecology. Durham, NC: Duke University Press. Pp 3-42.

Bond, P. 2012. Why Jim Kim should resign from the World Bank. Counterpunch. [accessed April 202014 ].

Brawner, J. 2015. Permaculture in the margins: realizing Central European regeneration. Journal of Political Ecology 22: 429-444. 
Brown, L. 2011. World on the edge: how to prevent environmental and economic collapse. New York: W. W. Norton and Company.

Burke, B. and B. Shear. 2014. Introduction: engaged scholarship for non-capitalist political ecologies. Journal of Political Ecology 21: 127-144.

Cadieux, K.V. and R. Slocum. 2015. What does it mean to do food justice? Journal of Political Ecology 22: $1-26$.

Campbell, B.C. and J.R. Veteto. 2015. Free seeds and food sovereignty: anthropology and grassroots agrobiodiversity conservation strategies in the US South. Journal of Political Ecology 22: 445-465.

Checker, M. 2007. "But I know it's true": environmental risk assessment, justice, and anthropology. Human Organization 66(2): 112-124.

Cleveland, D.A. 2014. Balancing on a planet: the future of food and agriculture. Berkeley, Los Angeles, London: University of California Press.

Crate, S.N. and M. Nuttall (eds.). 2009. Anthropology and climate change: from encounters to actions. Walnut Creek, CA: Left Coast Press.

Deresiewicz. 2011. Faulty towers: the crisis in higher education. The Nation. [accessed May 4 2014]. http://www.thenation.com/article/160410/faulty-towers-crisis-higher- education?page $=0,0$

Deloria, V. 1969. Custer died for your sins. London, Ontario: Collier-Macmillan.

Deloria, V. 1979. The metaphysics of modern existence. San Francisco: Harper and Row.

Descola, P. 2013. Beyond nature and culture. Chicago, IL: The University of Chicago Press.

Donham, D.L. 1999. Marxist modern: an ethnographic history of the Ethiopian revolution. Berkeley and Los Angeles, CA: University of California Press.

Egan, F. 2005 (orig. 2001). The historical ecology handbook: a restorationist's guide to reference ecosystems. Washington D.C.: Island Press.

Escobar, A. 1991. Anthropology and the development encounter: the making and marketing of development anthropology. American Ethnologist 18(4): 658-682.

Escobar, A. 1995. Encountering development: the making and unmaking of the third world. Princeton: Princeton University Press.

Escobar, A. 2001. Culture sits in places: reflections on globalism and subaltern strategies of localization. Political Geography 20:139-174.

Escobar, A. 2008. Territories of difference: place, movements, life, redes. Durham, NC: Duke University Press.

Fuentes-Nieva, R., N. Galasso, 2014. Working for the few: political capture and economic inequality. Oxfam Briefing Paper. Oxford, UK: Oxfam GB.

González, R.J. 2012. "Human terrain": past, present, and future applications. In A.C.G.M. Robben and J.A. Sluka (eds.) Ethnographic fieldwork: an anthropological reader (Second Ed.). Malden MA, Oxford UK: Wiley-Blackwell. Pp 593-604.

Harvey, D. 2005. A brief history of neoliberalism. Oxford, UK: Oxford University Press.

Henry, L., M. Nuñez-Janes, A. Jordan, and A.R. Cruz. 2013. Synonyms for engagement: forging an engaged anthropology in north Texas. Annals of Anthropological Practice 37(1): 90-112.

Hunn, E.S. 1999. The value of subsistence for the future of the world. In V.D. Nazarea (ed.) Ethnoecology: situated knowledge/located lives. Tucson: University of Arizona Press. Pp 23-36.

IPCC. 2013. Summary for policymakers. In T.F. Stocker, D. Qin, G.-K. Plattner, M. Tignor, S.K. Allen, J. Boschung, A. Nauels, Y. Xia, V. Bex, and P. M. Midgley (eds.) Climate change 2013: the physical science basis. Contribution of Working Group I to the Fifth assessment report of the Intergovernmental Panel on Climate Change. Cambridge, UK; New York, NY, USA: Cambridge University Press.

Ingold, T. 2011. Being alive: essays on movement, knowledge and description. New York: Routledge. 
James, W. 1973. The anthropologist as reluctant imperialist. In T. Asad (ed.) Anthropology and the colonial encounter. New York: Ithaca Press. Pp 41-70.

Johnston, B.R. 2007. Half-lives and half-truths: confronting the radioactive legacy of the cold war. Santa Fe, NM: School for Advanced Research Press.

Johnston, B.R. 2011. Life and death matters: human rights, environment, and social justice (Second Edition). Walnut Creek, CA: Left Coast Press.

Latour, B. 1993. We have never been modern. Cambridge, MA: Harvard University Press.

Latour, B. 2014. Another way to compose the common world. HAU: Journal of Ethnographic Theory 4: 301307.

Little, P.C. 2013. Envisioning the political ecology of mitigation in a microelectronic disaster setting. Journal of Political Ecology 20: 217-237.

Lockyer, J. 2010a. Intentional community carbon reduction and climate change action: from ecovillages to transition towns. In M. Peters, S. Fudge, and T. Jackson (eds.) Low carbon communities: imaginative approaches to combating climate change locally. UK: Edward Elgar Publishing. Pp 197-215.

Lockyer, J. 2010b. Intentional communities and sustainability. Communal Societies 30(1): 17-30.

Lockyer, J. and J.R. Veteto. 2012. Ecovillages. In S.G. Beavis, M. Dougherty, and T. Gonzales (eds.) The encyclopedia of sustainability: vol. 8. The Americas and Oceania: assessing sustainability. Great Barrington, MA: Berkshire Publishing. Pp 92-95.

Lockyer, J. and J.R. Veteto. 2013. Environmental anthropology engaging ecotopia: bioregionalism, permaculture, and ecovillages. New York, London: Berghahn Books.

Maffi, L. 2001. On biocultural diversity: linking language, knowledge, and the environment. Washington D.C.: Smithsonian Institute Press.

Marcus, G.E. and M.M.J. Fischer. 1999. Anthropology as cultural critique: an experimental moment in the human sciences (Second Ed.). Chicago, London: The University of Chicago Press.

Martinez, D. 2003. Protected areas, Indigenous peoples, and the western idea of nature. Ecological Restoration 21(4): 247-250.

McKenna, B. 2012. Greening anthropology. In S.D. Fassbinder, A.J. Nocella II and R. Kahn (eds.) Greening the academy: ecopedagogy through the liberal arts. Rotterdam/Boston/Taipai: Sense Publishers. Pp 141-160.

Meek D. 2015. Taking research with its roots: restructuring schools in the Brazilian landless workers' movement upon the principles of a political ecology of education. Journal of Political Ecology 22: 410-428.

Miller, T. 2011. The contingency of (some) academic labor: communication studies and the cognitariat. International Journal of Communication 5: 1837-1842.

Nabhan, G.P. 1989. Enduring seeds: Native American agriculture and wild plant conservation. Tucson: The University of Arizona Press.

Nabhan, G.P. 1997. Cultures of habitat: on nature, culture, and story. Washington, DC: Counterpoint.

Nabhan, G.P. 2002. Coming home to home to eat: the pleasure and politics of local food. New York, NY: W. W. Norton and Company.

Nabhan, G.P. (ed.) 2008. Renewing America's food traditions: saving and savoring the continent's most endangered foods. Vermont: Chelsea Green Publishing.

Nabhan, G.P. 2013. Growing food in a hotter, drier, land: lessons from desert farmers on adapting to climate uncertainty. White River Junction, VT: Chelsea Green Publishing.

Radonic L. and S. Kelly-Richards. 2015. Pipes and praxis: a methodological contribution to the urban political ecology of water. Journal of Political Ecology 22: 389-409.

Rhoades, R.E. 2005. Agricultural anthropology. In S. Kedia and J.V. Willigen (eds.) Applied anthropology: domains of application. Westport, CT: Praeger. Pp 61-83.

Rhoades, R.E. 2007. Listening to the mountains. Dubuque, Iowa: Kendall/Hunt Publishing. 
Rhoades, R.E. and R. Booth. 1982. Farmer-back-to-farmer: a model for generating acceptable agricultural technology. Agricultural Administration 11:127-137.

Salmon, E. 2003. Kincentric ecology: indigenous perceptions of the human-nature relationship. Ecological Applications 10(5): 1327-1332.

Salmon, E. 2012. Eating the landscape: American Indian stories of food, identity, and resilience. Tucson: University of Arizona Press.

Saxton, D. 2015. Ethnographic movement methods: anthropology takes on the pesticide industry. Journal of Political Ecology 22: 368-388.

Scheper-Hughes, Nancy. 1995. The primacy of the ethical: propositions for a militant anthropology. Current Anthropology 36(3): 409-440.

Simonelli, J. 2014. Home rule and natural gas development in New York: civil fracking rights. Journal of Political Ecology 21:258-278.

Singer, N. 2014. Intel's sharp-eyed social scientist. The New York Times. [accessed June 14 2014]. http://www.nytimes.com/2014/02/16/technology/intels-sharp-eyed-social-scientist.html

Starn, O. 1986. Engineering internment: anthropologists and the war relocation authority. American Ethnologist 13(4): 700-720.

Sutherland, W.J. 2003. Parallel extinction risk and global distribution of languages and species. Nature 423: 276-279.

Treanor, P. 2005. Neoliberalism: origins, theory, definition. [accessed December 2 2014]. http://web.inter.nl.net/users/Paul.Treanor/neoliberalism.html

Veteto, J.R. 2014. Seeds of persistence: agrobiodiversity in the American Mountain South. Culture, Agriculture, Food, and Environment 36(1): 17-27.

Veteto, J.R. and J. Lockyer. 2008. Environmental anthropology engaging permaculture: moving theory and practice toward sustainability. Culture and Agriculture 30(1-2): 47-58.

Veteto, J.R. and S.B. Carlson. 2014. Climate change and apple diversity: local perceptions from Appalachian North Carolina. Journal of Ethnobiology 34(3): 359-382.

Veteto, J.R. and T.A. Crane. 2014. Tending the field: special issue on agricultural anthropology and Robert E. Rhoades. Culture, Agriculture, Food, and Environment 36(1): 1-3.

Wackernagel, M., N.B. Schulz, D. Deumling, A.C. Linares, M. Jenkins, V. Kapos, C. Monfreda, J. Loh, N. Myers, R. Norgaard, and J. Randers. 2002. Tracking the ecological overshoot of the human economy. Proceedings of the National Academy of Sciences 99(14): 9266-9271.

Wasson, C. 2000. Ethnography in the field of design. Human Organization 59(4): 377-388.

Willow, A. 2012. Strong hearts, native lands: the cultural and political landscape of Anishinaabe anticlearcutting activism. Albany: State University of New York Press.

Willow, A. and A. Wylie. 2014. Politics, ecology, and the new anthropology of energy: exploring the emerging frontiers of hydraulic fracking. Journal of Political Ecology 21:222-236.

Wolverton, S., K.J. Chambers and J.R. Veteto. 2014. Climate change and ethnobiology. Journal of Ethnobiology 34(3): 273-275.

Zalasiewicz, J., M. Williams, A. Haywood, and M. Ellis. 2011. The Anthropocene: a new epoch of geological time? Philosophical Transactions of the Royal Society A 369: 835-841. 